\title{
Modelagem Matemática da Imunologia de HIV: Estudo das Células de Defesa Ativada
}

\author{
Camila Vianna de Magalhães* Roberto C. A. Thomé $\quad$ Dayse Haime Pastore \\ DIPPG - Diretoria de Pesquisa e Pós Graduação, \\ CEFET/RJ - Centro de Educação Tecnológica Celso Suckow da Fonseca, \\ 20271-110, Maracanã, Rio de Janeiro, RJ \\ E-mail: milamagal@yahoo.com.br, rthome@cefet-rj.br, dpastore@cefet-rj.br, \\ Hyun Mo Yang \\ UNICAMP - IMECC, Departamento de Matemática Aplicada \\ 13083-970, Campus Universitário Zeferino Vaz, Barão Geraldo, Campinas - SP \\ E-mail: hyunyang@ime.unicamp.br
}

\section{$\underline{\text { RESUMO }}$}

Estudamos um modelo matemático que descreve a dinâmica de propagação do HIV no organismo humano. Este modelo é apresentado por meio de um sistema de equações diferenciais ordinárias que envolvem células suscetíveis, células infectadas, HIV, células de defesa e células de defesa ativas. A diferença desse modelo para outros encontrados na literatura são exatamente dois momentos de atuação do sistema imunológico na defesa contra o HIV: as células sem ativação para o HIV e as células ativadas para o HIV.

$\mathrm{O}$ vírus da Imunodeficiência Humana, também conhecido como HIV, (sigla em inglês para human immunodeficiency virus), é da família dos retrovírus e o responsável pela AIDS. A infecção pelo HIV resulta em uma doença crônica e progressiva, que pode levar à destruição do sistema imunológico. A evolução da doença se caracteriza por uma elevada taxa de replicação viral, que resulta na emergência de variantes virais mais virulentas. A infecção pelo HIV é, atualmente, delineada pela contagem do número de células $C D 4+$ pela quantidade de partículas virais no sangue (carga viral) e pelos sintomas clínicos.

Para se reproduzir, o HIV une-se à membrana de uma célula vital para o sistema imunológico, a T4. O vírus libera seu RNA e uma enzima, a transcriptase reversa, com a qual fabrica o DNA viral. O $D N A$ viral entra no núcleo e une-se ao DNA da célula, assumindo o comando. O resultado dessa união é o DNA Pró-Viral que fabrica o RNA mensageiro com o código genético do vírus. O RNA mensageiro desloca-se para o citoplasma e produz os Vírions. Os Vírions saem da célula hospedeira como novos HIV's. Um único vírus gera muitos outros pontos para infectarem outras células (Amendoeira, 2009).

O modelo proposto apresenta-se com a introdução de uma nova variável que é chamada de células específicas de defesa ativada. Consideramos que isso é extremamente importante para o modelo uma vez que em nosso organismo já possuímos células de defesa estando contaminado ou não. Faz parte do conjunto de células de qualquer indivíduo, possuir células suscetíveis e células de defesa que estão prontas para nos defender desde uma simples infecção até algo mais grave. Com a contaminação pelo $H I V$, o que ocorre é justamente a destruição dessas células que ficam impedidas de nos defender de uma simples gripe podendo tornar-se algo muito mais perigoso ao nosso organismo. Sendo assim, uma vez contaminada, a pessoa passa a ter também, células infectadas, vírus e células especificas de defesa ativada que estarão ali presentes com o intuito de tentar destruir exatamente o $H I V$.

Neste trabalho, estamos propondo um novo modelo matemático para estudar a dinâmica do HIV no sistema imunológico humano. Estamos propondo modificações de vários modelos existentes na litera-

*bolsista de Iniciação Científica PIBIC/CNPq 
tura (Grégio et al., 2009, Komarova et al., 2001, Nowak et al., 2000 \& Perelson et al., 1999). Uma delas é introdução de uma nova variável para melhor descrever a defesa do sistema imunológico. Esse modelo é dado pelo sistema de equações diferenciais ordinárias que reproduziremos a seguir:

$$
\left\{\begin{aligned}
\dot{x} & =\lambda_{x}-\mu_{x} x-\beta_{v} x v \\
\dot{y} & =\beta_{v} x v-\mu_{y} y-p_{y} y z_{a} \\
\dot{v} & =k_{v} \mu_{y} y-\mu_{v} v-p_{v} v z_{a} \\
\dot{z} & =\lambda_{z}-\mu_{z} z-\beta_{z} z v \\
\dot{z}_{a} & =\beta_{z} z v-\mu_{z} z_{a}
\end{aligned}\right.
$$

Nesse modelo, as células $T C D 4+$ existentes no organismo (suscetíveis) são representadas por $x$, as células $T C D_{4}+$ infectadas pelo $H I V$ por $y$, os $H I V^{\prime} s$ livres no organismo por $v$, as células de defesa $T C D 8+$ específicas para o $H I V$ por $z$, e as células de defesa ativada por $z_{a}$. Para cada variável existe sua respectiva mortalidade, representadas por $\mu$ seguido da variável correspondente. Além disso, existe também, o número médio de vírus livre liberado por uma célula infectada representado por $k_{v}$, a taxa de ativação da resposta imunológica $\beta_{z}$, a taxa de infecção do vírus $\beta_{v}$, a taxa de destruição de células infectadas $p_{y}$, taxa de destruição dos vírus $p_{v}$, a taxa de suprimento das células suscetíveis $\lambda_{x}$ e a taxa de suprimento das células de defesa $\lambda_{z}$. No sistema (1), a variável $z$ é a população de todas as células efetoras da resposta imunológica em repouso e a variável $z_{a}$ é a população dessas células ativadas no combate as células infectadas, que está respondendo com anticorpos.

Nas simulações numéricas do problema sem controle escolhemos o período de 100 dias para representar um paciente infectado pelo $H I V$ por cerca de 3 meses e que não recebeu nenhum tipo de tratamento. Após o período de um mês, podemos perceber um grande aumento do número de vírus e das células infectadas. Além disso, é possível perceber o decaimento das células suscetíveis e das células de defesa efetoras da resposta imunológica. O modelo proposto descreve de maneira aceitável o comportamento do $H I V$ no organismo humano, assim como fazem os demais modelos. O diferencial nesse modelo é podermos analisar separadamente as células de defesa ativada. Percebemos uma migração das células de defesa para o compartimento das células de defesa ativada. Acreditamos que isso possa levar, com o passar dos anos, a saturação do sistema imunológico. Além disso, os resultados parecem sugerir uma tendência para um dos pontos de equilíbrio não-trivial do sistema dinâmico.

Palavras-chave: AIDS, HIV, Modelagem Matemática, Células de Defesa Ativada

\section{Referências}

[1] Amendoeira, M, 2009. Conceitos e métodos para a formação de profissionais em laboratórios de saúde. EPSJV, Rio de JANEIRO.

[2] Grégio J.M, Caetano M.A.L, and Yoneyama T. State estimation and optimal long period clinical treatment of HIV seropositive patients. Anais da Academia Brasileira de Ciências, 81:3 12, 03 2009.

[3] Komarova N and, Nowak M.A. The evolutionary dynamics of the lexical matrix. Bulletin of Mathematical Biology, 63:451484, 2001.

[4] Nowak M, and May R.M, Virus dynamics mathematical principles of immunology and virology. Oxford, 2000.

[5] Perelson A.S and Patrick W. N. Mathematical analysis of HIV-1 dynamics in vivo. SIAM Rev., 41(1):344 (electronic), 1999. 